\title{
Performance of ASHRAE models in assessing pollutant dispersion from rooftop emissions
}

\author{
B. Hajra ${ }^{a^{*}}$ T. Stathopoulos ${ }^{\mathrm{a}}$, A. Bahloul ${ }^{\mathrm{b}}$ \\ ${ }^{\text {a }}$ Centre for Building Studies, Department of Building, Civil and Environmental \\ Engineering, Concordia University, Montreal, Canada \\ ${ }^{\mathrm{b}}$ Institut de recherche Robert-Sauvé en santé et en sécurité du travail, Montreal, Canada
}

\begin{abstract}
The performance of different ASHRAE models besides their general development since 1997 forms the basis of this paper. The experimental results of a few recent nearfield pollutant dispersion studies are compared to ASHRAE models. These cases include isolated buildings and adjacent building configurations. The results from this study show that ASHRAE 2011 provide reasonable dilution estimates for low exhaust momentum ratios $(\mathrm{M})$, while previous ASHRAE models predict lower dilutions than wind tunnel data for all cases. In fact, ASHRAE can only be used to estimate rooftop dilutions on an emitting building, and does not provide formulations to estimate dilutions on adjacent building surfaces. However, unlike previous versions, ASHRAE 2011 predicts reasonable dilutions on the leeward wall of the emitting building, which is an important contribution of the current ASHRAE model. It is suggested that future ASHRAE versions should be capable of estimating reasonable dilutions on adjacent building surfaces for realistic urban scenarios, by taking into account the spacing between buildings.
\end{abstract}

Keywords: ASHRAE; Building configurations; Pollutant dispersion; Wind tunnel; Urban scenario 


\section{Introduction}

Pollutants released from a rooftop stack can enter an adjacent building, thereby severely affecting the health of occupants. Although wind tunnel and field measurements give accurate assessments of plume dilutions, they are often expensive and time consuming (Stathopoulos et al. 2008). Many designers use Gaussian based dispersion models such as: Atmospheric Dispersion Modelling System (ADMS) and Industrial Source Complex (ISC) to simulate pollutant dispersion in the urban environment (Touma et al., 2006; Holmes and Morawska, 2006). However, studies by Stathopoulos et al., 2008 have shown the inability of most dispersion models to accurately simulate near-field pollutant dispersion from rooftop exhausts. Computational Fluid Dynamics (CFD) has also been applied to simulate near-field dispersion problems, including toxic and odorous pollutants (e.g. Labovsky and Jelemensky, 2011). However, according to ASHRAE 2011, "CFD models can both over- and underpredict concentration levels by orders of magnitude, leading to potentially unsafe designs". ASHRAE has been used for several decades by designers to predict the suitable location of rooftop stacks and intakes to avoid plume re-ingestion (e.g. Petersen et al., 2004), and hence has been used for the present study.

ASHRAE 1997 and 1999 models were primarily based on the findings of Halitsky, 1963, which gave an overview of the air and pollutant flow characteristics around a building. Later, Wilson and his associates developed Gaussian based formulations for estimating plume dilutions in various versions of ASHRAE which were published in 2003 and 2007. Recently, ASHRAE 2011 was introduced based on the works of Petersen et al. 2004. Unfortunately, most ASHRAE models prior to 2011 were found to be overly conservative for isolated buildings with flat roofs and those having a rooftop structure, as well as adjacent building configurations (Stathopoulos et al. 2008). Hajra et al., 2011 performed a detailed wind tunnel study of near-field pollutant dispersion for upstream building configurations. The study focussed on plume characteristics due to change in various parameters, such as building dimensions, stack location and height, exhaust parameters and wind azimuth. ASHRAE 2007 model was compared to the experimental results of that study, and the latter was found to be overly conservative for all upstream configurations. The present study was an effort to assess various ASHRAE models (1997, 
1999, 2003, 2007 and 2011) by applying them for different urban scenarios (upstream configurations and downstream configurations). The main idea of this paper is to show how the different versions of ASHRAE models perform for such adjacent building configurations. Despite increased urbanisation, the different versions of ASHRAE only focus on isolated buildings that seldom exist in an urban environment.

This paper reviews various ASHRAE models (1997, 1999, 2003, 2007 and 2011) and compares them with some recent experimental findings for isolated and adjacent building configurations. Results show that ASHRAE 2011 compares well with wind tunnel roof dilutions for cases with low $\mathrm{M}$ values $(\mathrm{M}<3)$, while the remaining ASHRAE models produce lower roof dilutions than experimental data for all building configurations. However, ASHRAE 2011 provides reasonable dilution estimates on the leeward wall of the emitting building. It is understandable, that additional wind tunnel studies representing a more urban environment must be carried out to improve future ASHRAE models.

\section{Wind tunnel testing of different building configurations}

Concentration measurements for various configurations consisting of buildings of different geometries placed upstream/downstream of an emitting building were carried out in the Boundary Layer Wind Tunnel Laboratory of Concordia University, Canada, which is $1.8 \mathrm{~m}$ square in section and $12.2 \mathrm{~m}$ long. A scale of 1:200 was used for the study. The wind velocity measured at the building height $\left(\mathrm{U}_{\mathrm{H}}\right)$ was $6.2 \mathrm{~m} / \mathrm{s}$. A thick atmospheric boundary layer was generated using spires that act as vortex generators, and coarse roughness elements $(5 \mathrm{~cm}$ cubes) staggered $6 \mathrm{~cm}$ from each other. A power law exponent $(\alpha)$ of 0.31 , which corresponds to an urban terrain according to ASHRAE 2009, was used for the study. Experimental conditions - see Table 1 - used for both studies were identical (Hajra et al. 2011; Hajra and Stathopoulos. 2012). For the lowest exhaust speed $(M=1)$, the building and stack Reynolds number were measured to be 20000 and 1800 respectively. Snyder, 1981 suggested that for proper simulation of non-buoyant tracer dispersion studies in the wind tunnel, the building and stack Reynolds number must exceed 11000 and 2000 respectively, which was later also verified by Arya and Lape, 1990 through wind tunnel measurements. According to Saathoff et al., 1995, "It is 
usually not possible to satisfy the stack Reynolds number criterion for small diameter stacks and it is also difficult to trip the flow for such stacks". In the present study, for M > 1, stack Reynolds number always exceeded 2000. However, Stathopoulos et al., 2008 have shown that even if the stack Reynolds number is somewhat less than 2000 for low $\mathrm{M}$ values, it does not affect the accuracy of the measurements. Also, for low M values ( $M$ $=1$ ), atmospheric turbulence is more dominant after the plume exits the stack, and hence, stack Reynolds number is not so important.

Table 1 Experimental parameters used for both studies

\begin{tabular}{|l|l|}
\hline Experimental parameters & Wind tunnel values \\
\hline Model scale & $1: 200$ \\
\hline Boundary layer depth $(\delta)$ & $95 \mathrm{~cm}$ \\
\hline Wind speed at building height $\left(\mathrm{U}_{\mathrm{H}}\right)$ & $6.2 \mathrm{~m} / \mathrm{s}$ \\
\hline Power law exponent $(\alpha)$ & 0.31 \\
\hline Upstream terrain & Urban \\
\hline Velocity at gradient height $\left(\mathrm{V}_{\mathrm{g}}\right)$ & $14.2 \mathrm{~m} / \mathrm{s}$ \\
\hline Roughness length of upstream exposure & $3.5 \mathrm{~mm}$ \\
\hline Longitudinal integral scale & $0.4 \mathrm{~m}$ \\
\hline Stack diameter $\left(\mathrm{d}_{\mathrm{e}}\right)$ & $0.3 \mathrm{~cm}$ \\
\hline Averaging time $\left(\mathrm{t}_{\mathrm{avg}}\right)$ & $1 \mathrm{minute}$ \\
\hline Upstream turbulence at building height $\left(\sigma_{\mathrm{H}} / \mathrm{U}_{\mathrm{H}}\right)$ & 0.23 \\
\hline
\end{tabular}

Building configurations found to be more critical in Hajra et al., 2011 and Hajra and Stathopoulos, 2012, have been considered here in order to assess the ASHRAE models. The basic building configurations showing the location of receptors and stack are shown in Figure 1. Configuration 1 consists of an isolated building $\left(B_{1}\right)$ while Configurations 2 and 3 consist of a taller upstream building ( $B_{2}$ upstream of $\left.B_{1}\right)$ and a taller downstream building ( $\mathrm{B}_{2}$ downstream of $\mathrm{B}_{1}$ ) respectively. The spacing between buildings ( $\mathrm{S} 1$ or $\mathrm{S} 2$ ) was varied from 10 to $50 \mathrm{~m}$, and the stack location $\left(\mathrm{X}_{\mathrm{s}}\right)$ was varied from 0 to $20 \mathrm{~m}$. The receptors were located $5 \mathrm{~m}$ apart on all surfaces, except on the wind ward wall of $\mathrm{B}_{2}$ (Configuration 2) and the leeward wall of $\mathrm{B}_{2}$ (Configuration 3) due to the plume characteristics.

Tracer gas $\left(\mathrm{SF}_{6}\right)$ was released from a rooftop stack for $\mathrm{M}$ ranging from 1 to 3, and stack heights $\left(h_{s}\right)$ ranging from 1 to $5 \mathrm{~m}$. A VARIAN 3400 Gas Chromatograph whose precision is $5 \%$ was used to estimate the concentration of the gas samples. The gas samples were collected using a syringe sampler at a sampling time of one minute due to 
the instrument features. Additional experimental details can be found in Hajra and Stathopoulos, 2012.

\section{ASHRAE dispersion model}

All versions of ASHRAE (1997, 1999, 2003, 2007 and 2011) suggest the following two methods for the evaluation of dispersion of pollutants on building roofs:

\section{a) Geometric design method \\ b) Exhaust dilution equations}

The former is used to assess the minimum height of a stack to avoid plume reingestion, based on the geometry of the plume, and is identical in all ASHRAE editions; the latter is used to assess plume dilutions on an isolated building roof surface and, has varied over the years.

Exhaust dilution equations

This section presents a short description of the dilution equations used in the different versions of ASHRAE.

\section{ASHRAE 1997/1999}

A summary of the main features is provided in Table 1, listing the major contributors and characteristics of each model.

ASHRAE 2003

ASHRAE 2003 suggests the estimation of the effective height of the plume (h) above the roof as:

$h=h_{s}+h_{r}-h_{d}$

where:

$\mathrm{h}_{\mathrm{s}}$ is stack height $(\mathrm{m})$,

$\mathrm{h}_{\mathrm{r}}$ is plume rise $(\mathrm{m})$ and

$h_{d}$ is the reduction in plume height due to entrainment into the stack wake during periods of strong winds (m). 
The plume rise is calculated using the formula of Briggs, 1984:

$h_{r}=3 \beta d_{e}\left(V_{e} / U_{H}\right)$

where:

$\mathrm{d}_{\mathrm{e}}$ is the stack diameter $(\mathrm{m})$,

$\mathrm{V}_{\mathrm{e}}$ is the exhaust velocity $(\mathrm{m} / \mathrm{s})$,

$\mathrm{U}_{\mathrm{H}}$ is the wind speed at building height $(\mathrm{m} / \mathrm{s})$; and

$\beta$ is the stack capping whose value is 1 for uncapped and 0 for capped stacks.

Wilson et al. 1998 introduced new formulations to assess plume spread parameters in ASHRAE 2003, which were not part of 1997 and 1999 versions.

As per ASHRAE 2003, dilution at roof level is expressed as:

$D_{r}=4\left(U_{H} / V_{e}\right)\left(\sigma_{y} / d_{e}\right)\left(\sigma_{z} / d_{e}\right) \exp \left(h^{2} / 2 \sigma_{z}^{2}\right)$

According to ASHRAE 2003 if $\mathrm{h}<\mathrm{H}_{\mathrm{c}}$, the dilution should be estimated by considering a flush vent $(h=0)$; however, if $h>H_{c}$, dilution may be estimated from equation 3. $\mathrm{H}_{\mathrm{c}}$ is defined as the height of the roof recirculation zone in ASHRAE 2003. Additionally the value of $\mathrm{h}^{2} / 2 \sigma_{\mathrm{z}}^{2}$ is restricted to 5 at points near the stack making the results overly conservative for isolated buildings (Stathopoulos et al. 2008).

ASHRAE 2007

The equations for estimating the spread parameters and plume height described in ASHRAE 2003 remain unchanged in ASHRAE 2007. However, the formulation for estimating rooftop dilution has been modified to:

$D_{r}=4\left(U_{H} / V_{e}\right)\left(\sigma_{y} / d_{e}\right)\left(\sigma_{z} / d_{e}\right) \exp \left(\zeta^{2} / 2 \sigma_{z}{ }^{2}\right)$

where: $\zeta=\mathrm{h}-\mathrm{H}_{\mathrm{c}}$

$$
=0 \text { if } \mathrm{h}<\mathrm{H}_{\mathrm{c}}
$$

$\zeta$ is the vertical separation between ' $h$ ' and $\mathrm{H}_{\mathrm{c}}$. 
For all cases the dilution calculated from Equations 3 and 4 have been converted to a normalised form according to Wilson et al. 1998 for ease of comparison with previous studies:

$$
\mathrm{D}_{\text {normalised }}=\left(\mathrm{D}_{\mathrm{r}} \mathrm{Q}\right) /\left(\mathrm{U}_{\mathrm{H}} \mathrm{H}^{2}\right)
$$

where

$\mathrm{Q}$ is the volumetric flow rate $\left(\mathrm{m}^{3} / \mathrm{s}\right)$,

$\mathrm{H}$ is the height of the low building $(\mathrm{m})$.

By comparing equations 3 and 4, one may observe that the exponential term in equation 4 becomes smaller because $\zeta$ is expressed as $\mathrm{h}-\mathrm{H}_{\mathrm{c}}$. In other words, the dilution is further reduced in 2007 as opposed to 2003, making the former more conservative than the latter (Stathopoulos et al. 2008). Both the 2003 and 2007 versions incorporate the effects of averaging time through the cross wind plume spread $\left(\sigma_{\mathrm{y}}\right)$.

\section{ASHRAE 2011}

The main differences in the current version are:

a) New formulations for estimating plume rise $\left(h_{r}\right)$ and plume spread parameters $\left(\sigma_{y}\right.$ and $\left.\sigma_{z}\right)$;

b) Provisions for estimating dilutions on the wall of the emitting building.

The plume rise $\left(h_{r}\right)$ from equation 2 is now estimated as

$h_{r}=\min \left\{\beta h_{x}, \beta h_{f}\right\}$

where

$h_{x}$ and $h_{f}$ are estimated as

$h_{x}=\left(\frac{3 V_{e}^{2} d_{e}{ }^{2} X}{4 \beta_{j}{ }^{2} U_{H}{ }^{2}}\right)^{1 / 3}$

$h_{f}=\frac{0.9\left[\left(V_{e}^{2} d_{e}^{2} / 4\right)\left(U_{H} / U_{*}\right)\right]^{0.5}}{\beta_{j} U_{H}}$

where 
$U *$ is the friction velocity $(\mathrm{m} / \mathrm{s})$,

$\beta_{j}$ is termed as jet entrainment coefficient

Unlike the 2007 version which calculates the spread parameters only in terms of M and $d_{e}$, ASHRAE 2011 uses the formulations developed by Cimoreli et al. 2005, which are based on turbulence intensities in $\mathrm{x}, \mathrm{y}$ and $\mathrm{z}$ directions, exhaust diameter $\left(\mathrm{d}_{\mathrm{e}}\right)$ and height of the building $(\mathrm{H})$. According to ASHRAE 2011, the dilution calculated from equation 4 corresponds to an averaging time of 10-15 minutes. Dilutions for shorter and longer averaging time using the 0.2 power law are suggested. ASHRAE 2011 also suggests in example 2 that dilution calculations must be carried out for three different roughness lengths $\left(Z_{o}\right)$, namely: $0.5 Z_{o}, 1.5 Z_{o}$ and $Z_{o}$, and the lowest dilution value must be chosen for the design. Additionally, following the recommendation of Petersen et al., 2004, dilutions can be estimated on the sidewall of a building based on the dilution obtained on the nearest rooftop receptor, by increasing the latter by a factor of 2 (for conservative values). One of the disadvantages of ASHRAE (past and present versions) is that it does not explicitly mention the range of applicability of each model. In the absence of wind tunnel measurements, a designer will normally use ASHRAE for predicting roof dilutions on the source for realistic urban scenarios (adjacent building configurations). This causes disparity between experimental findings and ASHRAE estimates, as discussed further.

Figure 2 shows comparisons for wind tunnel data from Hajra et al. 2011 for Configuration 1 (isolated building), ASHRAE 1997, 1999, 2003, 2007 and 2011 in terms of normalised dilutions for $\mathrm{h}_{\mathrm{s}}=3 \mathrm{~m}, \mathrm{M}=3$ and $\mathrm{X}_{\mathrm{s}}=20 \mathrm{~m}$. ASHRAE 1997 and 1999 have the same formulations and therefore predict similar dilutions at all receptors. In general, all ASHRAE models predict comparable dilutions beyond $15 \mathrm{~m}$ from the stack. It is observed that ASHRAE 1997/1999 predict lower dilutions than wind tunnel data within the first $10 \mathrm{~m}$ from the stack, because the formulations of Halitsky, 1963 are mainly suited for short stacks, making them more conservative. On the other hand, ASHRAE 2011 predicts lower plume rise than 2003 and 2007, resulting in lower dilutions in the first $10 \mathrm{~m}$ from the stack. Additional discussion on this subject can also be found in Gupta et al. 2012. An appendix showing the applications of ASHRAE 2007 
and 2011 models, corresponding to Figure 2 is presented at the end. Table 2 summarises the various versions of ASHRAE models, and their respective performances.

Table 2. Summary of various ASHRAE dispersion models and their respective features

\begin{tabular}{|c|c|c|}
\hline Model & * Based on the works of: & Main features \\
\hline ASHRAE 1997/1999 & $\begin{array}{ll}- & \text { Halitsky, 1963 } \\
- & \text { Wilson }(1979,1982) \\
- & \text { Wilson and Lamb, } \\
& 1994 \\
- & \text { Wilson and Chui } \\
& (1985,1987) \\
-\quad & \text { Chui and Wilson, } \\
& 1988 \\
\end{array}$ & 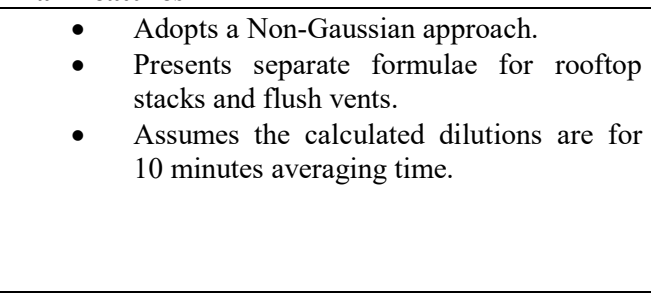 \\
\hline $\begin{array}{l}\text { ASHRAE } 2003 \\
\text { ASHRAE } 2007\end{array}$ & $\begin{array}{ll}- & \text { Wilson }(1979,1982) \\
\text { - } & \text { Wilson et al.1998 } \\
\text { - } & \text { Briggs, } 1984\end{array}$ & $\begin{array}{l}\text { - } \text { Limits }^{2} / 2 \sigma_{\mathrm{z}}{ }^{2} \text { to } 5 \text { for ASHRAE } 2003 \text { and } \\
7 \text { for ASHRAE } 2007 \text {, close to the stack. } \\
\text { - Considers } \sigma_{\mathrm{y}} \& \sigma_{\mathrm{z}} \text { to be functions of } \\
\text { exhaust diameter and receptor distance. } \\
\text { - Assumes initial spread }\left(\sigma_{\mathrm{o}}\right) \text { to be function } \\
\text { of } \mathrm{M} \text {. } \\
\text { - Assumes dilution estimates for } 2 \text { minutes } \\
\text { averaging time, and considers the dilution } \\
\text { values to be constant for longer averaging } \\
\text { times. }\end{array}$ \\
\hline ASHRAE 2011 & $\begin{array}{ll}\text { - } & \text { Wilson }(1979,1982) \\
\text { - } & \text { Wilson et al. 1998 } \\
\text { - } & \text { Cimorelli et al. } 2005 \\
\text { - } & \text { Petersen et al. 2004 }\end{array}$ & $\begin{array}{l}\text { - Considers no limit for } \mathrm{h}^{2} / 2 \sigma_{\mathrm{z}}^{2} \text { close to the } \\
\text { stack. } \\
\text { Assumes } \sigma_{\mathrm{y}} \& \sigma_{\mathrm{z}} \text { to be functions of } \\
\text { turbulence intensities and receptor } \\
\text { distance. } \\
\text { - Assumes initial spread }\left(\sigma_{\mathrm{o}}\right) \text { equal to } \\
0.35 \mathrm{~d}_{\mathrm{e}} \text {. } \\
\text { - States explicitly that dilution estimates for } \\
\text { ASHRAE } 2011 \text { are for } 10-15 \text { minutes } \\
\text { averaging time. } \\
\text { Provides provisions to estimate wall } \\
\text { dilutions on the emitting building. } \\
\text { Estimates the lowest dilution from three } \\
\text { different roughness lengths ( } \mathrm{Z}_{\mathrm{o}}, 0.5 \mathrm{Z}_{\mathrm{o}} \text {, } \\
\left.1.5 \mathrm{Z}_{\mathrm{o}}\right) \text {. }\end{array}$ \\
\hline
\end{tabular}

\section{Results and discussion}

This section presents comparisons for different ASHRAE models (1997, 1999, 2003, 2007 and 2011) and wind tunnel data. It may be mentioned that the 2003 and 2007 versions generally provide comparable dilutions for $\mathrm{h}_{\mathrm{s}}<5 \mathrm{~m}$ (Stathopoulos et al. 2008).

\section{Effect of a taller upstream building}

Figure 3 (a) compares ASHRAE 1997, 1999, 2003, 2007 and 2011 models, wind tunnel data from Configurations 1 and 2 for $\mathrm{h}_{\mathrm{s}}=1 \mathrm{~m}, \mathrm{~S} 1=20 \mathrm{~m}, \mathrm{M}=1$ and $\mathrm{X}_{\mathrm{s}}=20 \mathrm{~m}$. Results show that Configuration 2 predicts lower dilutions than Configuration 1 at all 
rooftop receptors. In fact, Configuration 2 generates dilutions upwind of the stack due to the plume characteristics (Hajra et al. 2011). ASHRAE 1997, 1999, 2003 and 2007 predict about 100 times lower dilutions than wind tunnel data of Configuration 2, due to reasons previously explained. ASHRAE 2011 predictions are lower than wind tunnel data of Configuration 2 very close to the stack due to lower plume rise. However, close to the downwind edge, the dilutions obtained by Configuration 2 are about a factor of 10 higher than ASHRAE 2011. This increase in dilutions by ASHRAE 2011 towards the downwind edge is because of the plume spread parameter $\left(\sigma_{\mathrm{y}}\right.$ and $\left.\sigma_{z}\right)$ evaluation, which is based on the turbulence intensities rather than $\mathrm{M}$ values. Additionally, none of the models take into account the effect of upstream buildings, and hence do not provide formulations to predict dilutions upwind of the stack. This trend changes slightly at $\mathrm{M}=3$, as shown in Figure 3 (b), where the dilutions obtained by ASHRAE 1997/1999 and 2011 are about 10 times lower than wind tunnel data of Configuration 2. ASHRAE 2003 and 2007 predictions are much lower than ASHRAE 2011 close to the downwind edge of $\mathrm{B}_{1}$. In general, the main problems with ASHRAE models include the inability to:

a) model upstream building effects;

b) provide formulations to estimate dilutions on adjacent building surfaces.

However, provisions for estimating dilutions on the building sidewalls (including leeward wall) of the emitting building are provided by ASHRAE 2011, based on the studies of Petersen et al., 2004. According to ASHRAE 2011, the dilution on the wall of an emitting building is obtained from the dilution calculated at the rooftop location above the wall receptor, by increasing the latter by a factor of 2 (for conservative estimates). For instance, Figure 4 presents comparisons for dilutions obtained from wind tunnel data and ASHRAE 2011 on the leeward wall of $B_{1}$ for Configuration 2 at $h_{s}=1 \mathrm{~m}, M=1 X_{s}=20$ $\mathrm{m}$. The dilutions on the leeward wall obtained from ASHRAE 2011 is found from the dilution estimated on the downwind edge of $B_{1}$ at $h_{s}=1 \mathrm{~m}$ and $\mathrm{M}=1$ (normalised dilution value of 0.7 obtained from Figure 3 (a) at receptor location of $50 \mathrm{~m}$ using ASHRAE 2011). This value is multiplied by 2, to obtain 1.4, as depicted in Figure 4. ASHRAE 2011 estimates were found to be only about a factor of 1.2 lower than wind tunnel data. Unlike previous versions, provision for estimating wall dilution is an important contribution of ASHRAE 2011. 
Effect of a taller downstream building (spacing)

The inability of ASHRAE models to simulate the effect of spacing between buildings is evident from Figure 5 (a), which compares ASHRAE 1997, 1999, 2003, 2007 and 2011 models, and Configurations 1 and 3 for $\mathrm{h}_{\mathrm{s}}=1 \mathrm{~m}, \mathrm{M}=1$ and $\mathrm{X}_{\mathrm{s}}=0$. At $\mathrm{S} 2=20 \mathrm{~m}$ and 25 $\mathrm{m}$, the dilutions obtained from Configuration 3 compare well at all receptors, and are somewhat lower than the isolated case (about a factor of 5). At $\mathrm{S} 2=30 \mathrm{~m}$, dilutions obtained from Configurations 1 and 3 are comparable at all receptors because the taller downstream building $\left(\mathrm{B}_{2}\right)$ is sufficiently away from the wake recirculation region of the low building $\left(B_{1}\right)$ (Hajra and Stathopoulos, 2012). A similar trend is observed at $h_{s}=1 \mathrm{~m}$ and $\mathrm{M}=3$, as shown in Figure 5 (b), although the dilutions are somewhat higher than those obtained at $M=1$. At $M=1$, with the exception of ASHRAE 2011, all other ASHRAE models continue to predict lower dilutions than wind tunnel data for Configuration 3, irrespective of spacing. Generally, ASHRAE 2011 compares well with the isolated case and Configuration 3 at spacing greater than $20 \mathrm{~m}$ at $\mathrm{M}=1$. However, at $\mathrm{M}=3$ all the ASHRAE models predict lower dilutions than wind tunnel data for both configurations, although ASHRAE 2011 predictions are somewhat higher than the other ASHRAE versions at receptors beyond $20 \mathrm{~m}$.

\section{Summary}

The reasons for the discrepancies between experimental data and ASHRAE models are summarised:

a) ASHRAE 1997 and 1999 models are only suited for short stacks, and do not account for plume rise and downwash effects. Hence, the results are generally lower than experimental data.

b) ASHRAE 2003 and 2007 predict low plume rise, causing the exponential term to be smaller, resulting in lower dilution estimates than wind tunnel data. This can result in an overly conservative design, as the cost of constructing a taller stack to disperse pollutants is greatly increased.

c) ASHRAE 2011 predicts somewhat better estimates as compared to previous versions, especially for low $M$ values $(M<3)$. However, for higher $M$ values $(M>1)$, the 
dilutions tend to be lower than wind tunnel data because the plume spread parameters are a function of turbulence intensities, and do not change with increasing $M$ values.

In general, none of the ASHRAE models take into account the effect of adjacent buildings, and hence, cannot predict dilutions on adjacent building surfaces. However, unlike previous versions, ASHRAE 2011 provides provisions to estimate wall dilutions on the emitting building, which is an important contribution of ASHRAE. It is understandable that additional wind tunnel experiments representing a more realistic urban scenario must be carried out in order to improve future ASHRAE models.

\section{Conclusions}

A detailed discussion of the various versions of $\operatorname{ASHRAE}(1997,1999,2003,2007$ and 2011), and their applications to near-field pollutant dispersion from rooftop exhausts, are presented in this paper. In general, it was observed that ASHRAE 2011 is more suited for low $\mathrm{M}$ values, while all other versions predict overly conservative estimates for all building configurations. In general, none of the models can be used to predict dilutions on adjacent building surfaces, and can only be used to estimate roof dilutions on the source.

Reasonable dilution estimates were obtained on the leeward wall of the emitting building as per ASHRAE 2011, which is an important contribution of the current ASHRAE model. Future ASHRAE versions must incorporate the effect of spacing between buildings, while developing formulations to estimate dilutions on adjacent building surfaces for realistic urban scenarios.

\section{Acknowledgements}

The authors gratefully acknowledge the financial support provided by Institut de recherche Robert-Sauvé en santé et en sécurité du travail (IRSST), Montreal, Canada for this research. 


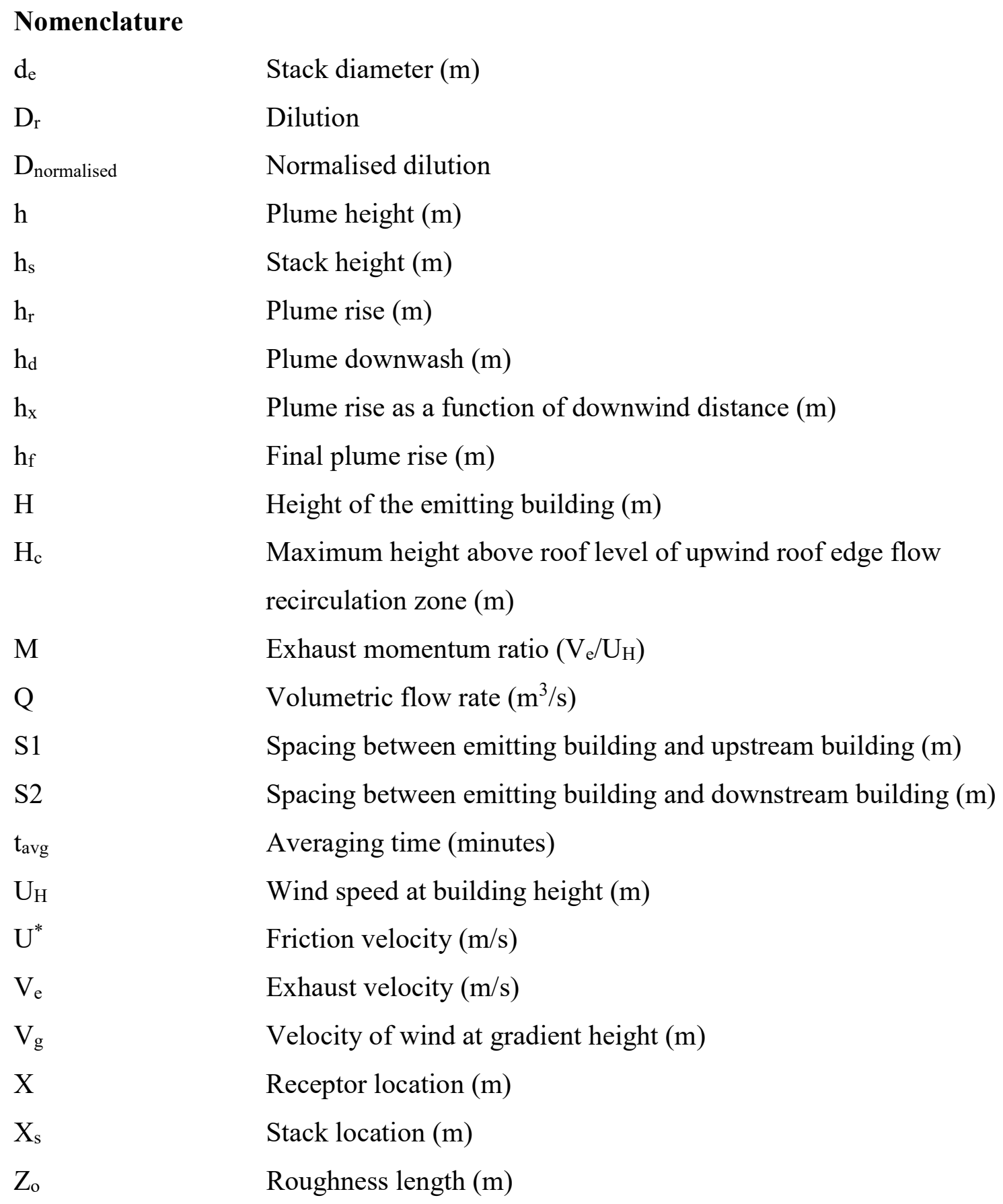

$\mathrm{d}_{\mathrm{e}}$

$\mathrm{D}_{\mathrm{r}}$

$D_{\text {normalised }}$

h

$\mathrm{h}_{\mathrm{s}}$

$\mathrm{h}_{\mathrm{r}}$

$\mathrm{h}_{\mathrm{d}}$

$\mathrm{h}_{\mathrm{x}}$

$\mathrm{h}_{\mathrm{f}}$

$\mathrm{H}$

$\mathrm{H}_{\mathrm{c}}$

M

Q

S1

S2

$t_{\text {avg }}$

$\mathrm{U}_{\mathrm{H}}$

$\mathrm{U}^{*}$

$\mathrm{V}_{\mathrm{e}}$

$V_{g}$

$\mathrm{X}$

$\mathrm{X}_{\mathrm{s}}$

$Z_{\mathrm{o}}$

Stack diameter (m)

Dilution

Normalised dilution

Plume height (m)

Stack height (m)

Plume rise (m)

Plume downwash (m)

Plume rise as a function of downwind distance $(\mathrm{m})$

Final plume rise $(\mathrm{m})$

Height of the emitting building (m)

Maximum height above roof level of upwind roof edge flow recirculation zone $(\mathrm{m})$

Exhaust momentum ratio $\left(\mathrm{V}_{\mathrm{e}} / \mathrm{U}_{\mathrm{H}}\right)$

Volumetric flow rate $\left(\mathrm{m}^{3} / \mathrm{s}\right)$

Spacing between emitting building and upstream building $(\mathrm{m})$

Spacing between emitting building and downstream building (m)

Averaging time (minutes)

Wind speed at building height $(\mathrm{m})$

Friction velocity $(\mathrm{m} / \mathrm{s})$

Exhaust velocity $(\mathrm{m} / \mathrm{s})$

Velocity of wind at gradient height (m)

Receptor location (m)

Stack location (m)

Roughness length (m)

\section{Greek symbols}

\section{$\alpha$}

$\beta$

$\beta_{\mathrm{j}}$

$\delta$
Power law exponent

Capping factor; $\beta=1$ for uncapped stacks $\& \beta=0$ for capped stacks

Jet entrainment coefficient

Boundary layer depth (m) 


$$
\begin{array}{ll}
\sigma_{\mathrm{y}} & \text { Standard deviation of cross-wind plume spread }(\mathrm{m}) \\
\sigma_{\mathrm{z}} & \text { Standard deviation of vertical plume spread }(\mathrm{m}) \\
\sigma_{\mathrm{H}} & \text { Standard deviation of wind speed at building height }(\mathrm{m}) \\
\zeta & \text { Vertical separation between } \mathrm{h} \text { and } \mathrm{H}_{\mathrm{c}}(\mathrm{m})
\end{array}
$$

\section{References}

Arya, S.P.S., Lape, J.F. 1990. A comparative study of the different criteria for the physical modeling of buoyant plume rise in a neutral atmosphere. Atmospheric Environment, 24, 289-295

ASHRAE 1997. Chapter 43. Building Air Intake and Exhaust Design. ASHRAE Applications Handbook American Society of Heating, Refrig. and Air-Cond. Eng., Inc., Atlanta, USA.

ASHRAE 1999. Chapter 43. Building Air Intake and Exhaust Design. ASHRAE Applications Handbook American Society of Heating, Refrig. and Air-Cond. Eng., Inc., Atlanta, USA.

ASHRAE 2003. Chapter 44. Building Air Intake and Exhaust Design. ASHRAE Applications Handbook, American Society of Heating, Refrig. and Air-Cond. Eng., Inc., Atlanta, USA.

ASHRAE 2007. Chapter 44. Building Air Intake and Exhaust Design. ASHRAE Applications Handbook, American Society of Heating, Refrig. and Air-Cond. Eng., Inc., Atlanta, USA.

ASHRAE. 2009. Airflow around Buildings. ASHRAE Applications Handbook, Chapter 24, American Society of Heating, Refrigerating and Air-Conditioning Engineers Inc., Atlanta, USA.

ASHRAE 2011. Chapter 45. Building Air Intake and Exhaust Design. ASHRAE Applications Handbook, American Society of Heating, Refrig. and Air-Cond. Eng., Inc., Atlanta, USA.

Briggs, G.A. 1984. Plume rise and buoyancy effects in Atmospheric Science and Power Production. Randerson. Ed, U.S. Department of energy D.O.E./TIC-27601 (DE 84005177), Washington, D.C, USA. 
Chui, E.H., Wilson, D.J. 1988. Effects of varying wind direction on exhaust gas dilution. Journal of Wind Engineering and Industrial Aerodynamics, 31, 87-104.

Cimoreli, A.J., Perry, S.G., Venkatram, A., Weil, J.C., Paine, R.J., Wilson, R.B., Lee, R.F., Peters, W.D., Brode, R.W. 2005. AERMOD: A dispersion model for industrial source applications. Part I: General model formulation and boundary layer characterisation. Applied Meteorology, 44, 682-693.

Gupta, A., Stathopoulos, T., Saathoff, P.J. 2012. Evaluation of ASHRAE dilution models to estimate dilution from rooftop exhausts. ASHRAE Transactions, 118, part 1, 200218.

Hajra, B., Stathopoulos, T., Bahloul, A. 2011. The effect of upstream buildings on nearfield pollutant dispersion in the built environment. Atmospheric Environment, 45, 4930-4940.

Hajra, B, Stathopoulos, T. 2012. A wind tunnel study of the effect of downstream buildings on near-field pollutant dispersion. Building and Environment, 52, 19-31.

Halitsky, J. 1963. Gas diffusion near buildings. ASHRAE Transactions, 69, 464-484.

Holmes, N.S., Morawska, L. 2006. A review of dispersion modelling and its application to the dispersion of particles: An overview of different dispersion models available. Atmospheric Environment, 40, 5902-5928.

Labovsky, J., Jelemensky, L. 2011. Verification of CFD pollution dispersion modelling based on experimental data. Journal of Loss Prevention in the Process Industries, 24, 166-177.

Petersen, R.L., Carter, J.J., Le-Compte, J. 2004. Exhaust contamination of hidden versus visible air intakes. ASHRAE Transactions, 110, 600-610.

Saathoff, P., Stathopoulos, T., Dobrescu, M. 1995. Effects of model scale in estimating pollutant dispersion near buildings. Journal of Wind Engineering and Industrial Aerodynamics, 54, 549-559.

Snyder W. H. 1981. Guidelines for fluid modelling of atmospheric diffusion. EPA office of Air quality, planning and standards, Research Triangle Park, USA, EPA-600/8-81009. 
Stathopoulos, T., Bahloul, A., Hajra, B. 2008. Analytical evaluation of the dispersion of polluting emissions from building stacks. Research report (R-576), Institut de recherche Robert Sauvé en santé et en sécurité du travail, Montreal, Canada.

Touma, J.S., Isakov, V., Ching, J., Seigneur, C. 2006. Air quality modelling of hazardous pollutants: Current status and future directions. Air and Waste Management Association, 56, 547-558.

Wilson, D.J. 1979. Flow patterns over flat-roofed buildings and application to exhaust stack design. ASHRAE Transactions, 85, part 2, 284-295.

Wilson, D.J. 1982. Critical wind speeds for maximum exhaust gas re-entry from flush vents at roof level intakes. ASHRAE Transactions 88 (1), 503-513.

Wilson, D.J., Chui, E. 1985. Influence of exhaust velocity and wind incidence angle on dilution from roof vents. ASHRAE Transactions, 91, 1693-1706.

Wilson, D.J., Chui, E. 1987. Effect of turbulence from upwind buildings on dilution of Exhaust gases. ASHRAE Transactions, 93, 2186-2197.

Wilson, D.J., Lamb, B. 1994. Dispersion of exhaust gases from roof level stacks and vents on a laboratory building. Atmospheric Environment, 28, 3099-3111.

Wilson, D.J., Fabris, I., Chen, J., Ackerman, M. 1998. Adjacent building effects on laboratory fume hood exhaust stack design. ASHRAE Research Report 897, American Society of Heating and Refrigerating and Air-conditioning Engineers, Atlanta, USA. 


\section{Appendix}

For the low-rise building considered in this study (refer to Figure 2), the receptor lying $20 \mathrm{~m}$ downwind of the stack has been chosen. Table 3 presents a summary of the calculations, which are common to both ASHRAE versions.

Table 3. Summary of calculations following ASHRAE 2007 and ASHRAE 2011 for Figure 2

\begin{tabular}{|l|l|l|}
\hline Parameter & Value used & Remark \\
\hline $\mathrm{h}_{\mathrm{s}}$ & $3 \mathrm{~m}$ & Chosen value of stack height pertaining to Figure 2 \\
\hline $\mathrm{d}_{\mathrm{e}}$ & $0.6 \mathrm{~m}$ & Stack diameter \\
\hline $\mathrm{M}$ & 3 & Exhaust momentum $\left(\mathrm{V}_{\mathrm{e}} / \mathrm{U}_{\mathrm{H}}\right)$ \\
\hline $\mathrm{U}_{\mathrm{H}}$ & $6.2 \mathrm{~m} / \mathrm{s}$ & Wind speed at building height $\mathrm{H}$, where $\mathrm{H}=15 \mathrm{~m}$ \\
\hline $\mathrm{h}_{\mathrm{d}}$ & $0 \mathrm{~m}$ & As per equation 9 in ASHRAE $2007 / 2011$ document \\
\hline $\mathrm{V}_{\mathrm{e}}$ & $18.6 \mathrm{~m} / \mathrm{s}$ & Exhaust velocity \\
\hline$\beta$ & 1 & Value for an uncapped stack \\
\hline $\mathrm{L}_{\mathrm{r}}$ & $22.31 \mathrm{~m}$ & Building recirculation length from equation 1 \\
\hline $\mathrm{H}_{\mathrm{c}}\left(\right.$ or $\left.\mathrm{h}_{\mathrm{Top}}\right)$ & $4.91 \mathrm{~m}$ & Height of recirculation zone from equation 2 \\
\hline $\mathrm{Q}$ & $5.26 \mathrm{~m} / \mathrm{s}$ & discharge rate of effluents from stack $\left(\pi \times 0.25 \times 0.6^{2} \times \mathrm{V}_{\mathrm{e}}\right)$ \\
\hline
\end{tabular}

\section{ASHRAE 2007}

ASHRAE 2007 defines a term called " $\zeta$ ", which is the vertical separation between plume height (h) and $\mathrm{h}_{\mathrm{Top}}$

Plume rise $\left(\mathrm{h}_{\mathrm{r}}\right)=5.4 \mathrm{~m}$ (from equation 2$)$

$\mathrm{h}=\mathrm{h}_{\mathrm{s}}+\mathrm{h}_{\mathrm{r}}-\mathrm{h}_{\mathrm{d}}=8.4>\mathrm{h}_{\mathrm{Top}}$

$\therefore \zeta=3.49 \mathrm{~m}$

At $X=20 \mathrm{~m}$

$\sigma_{\mathrm{y}} / \mathrm{d}_{\mathrm{e}}=6.512$ (from equation 20 in ASHRAE 2007, Chapter 44);

$\sigma_{\mathrm{z}} / \mathrm{d}_{\mathrm{e}}=5.337$ (from equation 21 in ASHRAE 2007, Chapter 44);

$\mathrm{D}_{\mathrm{r}}=83.39$ (from equation 4$)$;

$D_{\text {normalised }}=\mathbf{0 . 3 0 1}($ from equation 5) - see value in Figure 2. 


\section{ASHRAE 2011}

The plume rise is found from a series of calculations as described further:

Assume $Z_{o}=2 \mathrm{~m}$ for an urban terrain (from Table 1, ASHRAE 2011, Chapter 45)

$\mathrm{U}_{\mathrm{H}} / \mathrm{U}^{*}=5.03$ (ASHRAE 2011, Chapter 45);

$\mathrm{h}_{\mathrm{f}}=2.713 \mathrm{~m}($ from equation 8$)$;

$\mathrm{h}_{\mathrm{x}}=2.969 \mathrm{~m}$ (from equation 7);

$\therefore \mathrm{h}_{\mathrm{r}}=2.713 \mathrm{~m}$ (from equation 6$)$;

$\mathrm{h}=\mathrm{h}_{\mathrm{s}}+\mathrm{h}_{\mathrm{r}}-\mathrm{h}_{\mathrm{d}}=5.713$ (from equation 1 )

Since, $\mathrm{h}>\mathrm{h}_{\text {Top }}$

$\therefore \zeta=0.803 \mathrm{~m}$

$\mathrm{i}_{\mathrm{x}}=0.363$ (from ASHRAE 2011, Chapter 45);

$\mathrm{i}_{\mathrm{y}}=0.273$ (from ASHRAE 2011, Chapter 45);

$\mathrm{i}_{\mathrm{z}}=0.182($ from ASHRAE 2011, Chapter 45);

$\sigma_{\mathrm{y}}=5.464$ (from equation 20, ASHRAE 2011, Chapter 45);

$\sigma_{\mathrm{z}}=3.646$ (from equation 21, ASHRAE 2011, Chapter 45);

$\mathrm{D}_{\mathrm{r}}=73.86$ (from equation 4 );

$D_{\text {normalised }}=\mathbf{0 . 2 6 6}($ from equation 5) - see value in Figure 2.

ASHRAE 2011 also states that the calculations should be repeated for $0.5 Z_{\mathrm{o}}$ and 1.5 $\mathrm{Z}_{\mathrm{o}}$, and the lowest dilution must be considered for the design. For the present study, an urban terrain was considered $\left(Z_{o}=2 \mathrm{~m}\right)$, and it was found that dilutions at $0.5 Z_{\mathrm{o}}$ and $1.5 Z_{\mathrm{o}}$ would have made negligible changes. Therefore, ASHRAE 2011 dilution results were found for $Z_{o}=2 \mathrm{~m}$. 


\section{Configuration 1}

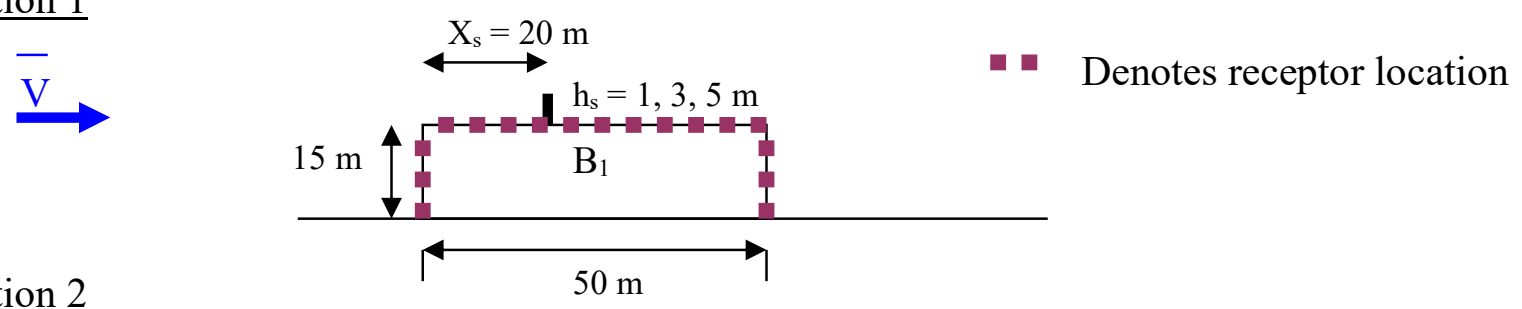

Configuration 2

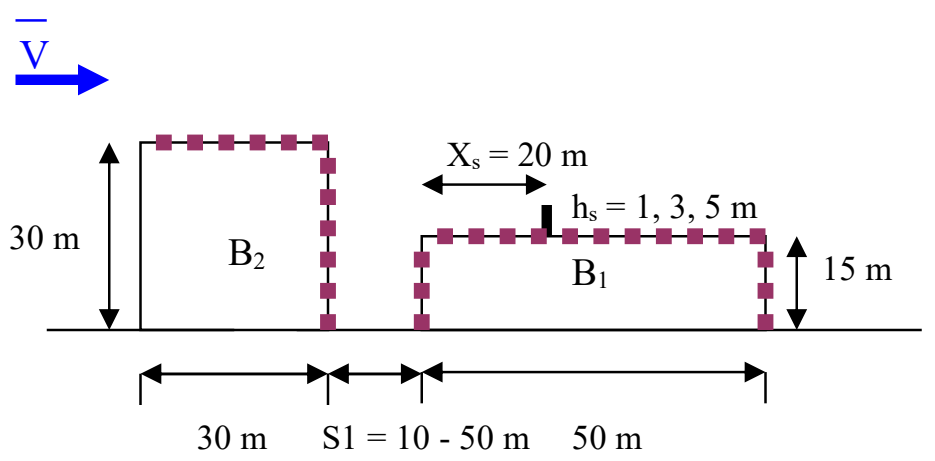

\section{Configuration 3}
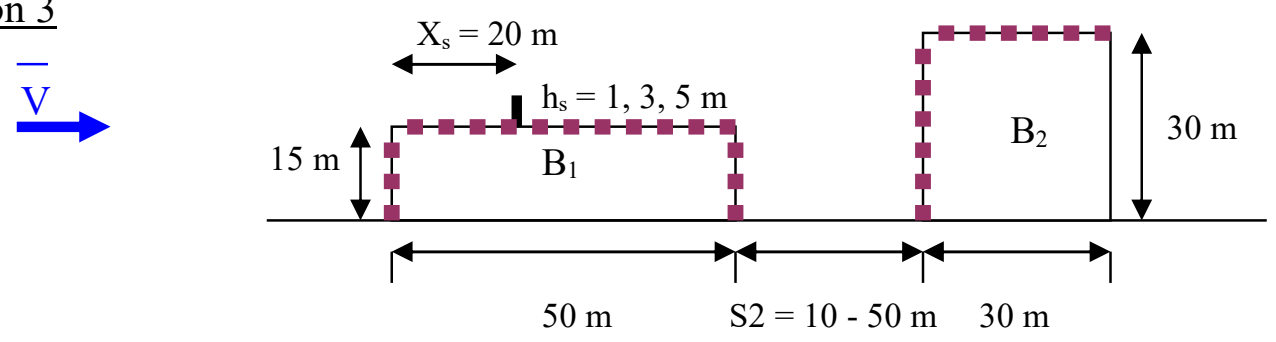

Figure 1: Low building $B_{1}$ (Configuration 1); $B_{2}$ upstream of $B_{1}$ (Configuration 2); $B_{2}$ downstream of $\mathrm{B}_{1}$ (Configuration 3)

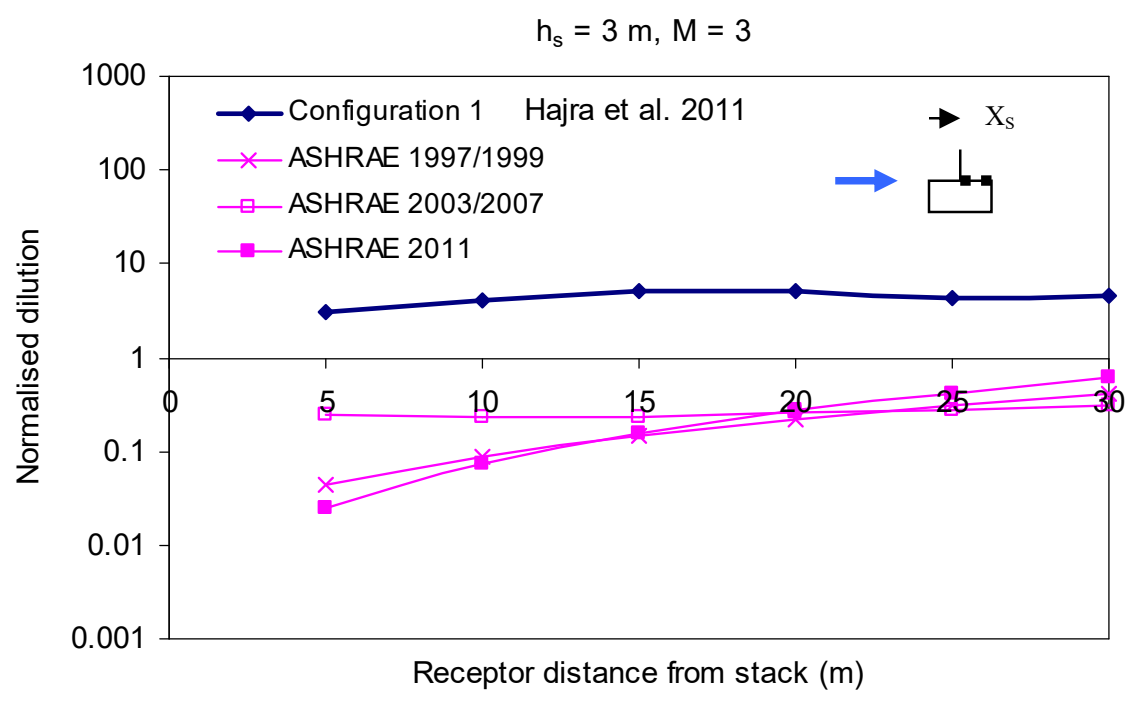

Figure 2 Normalised dilution on rooftop of low building $\left(B_{1}\right)$ for $h_{s}=3 \mathrm{~m}, X_{s}=20 \mathrm{~m}$ 


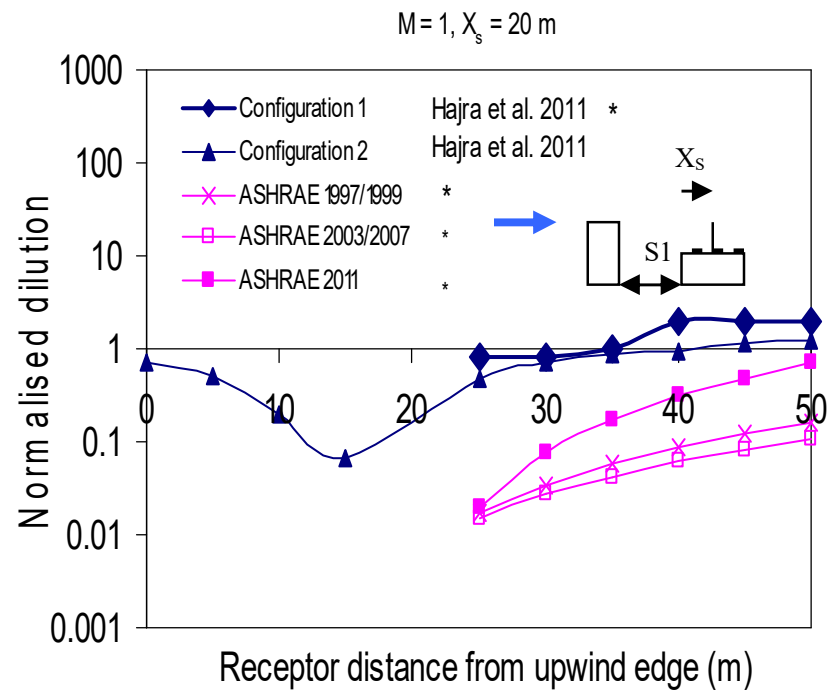

a)

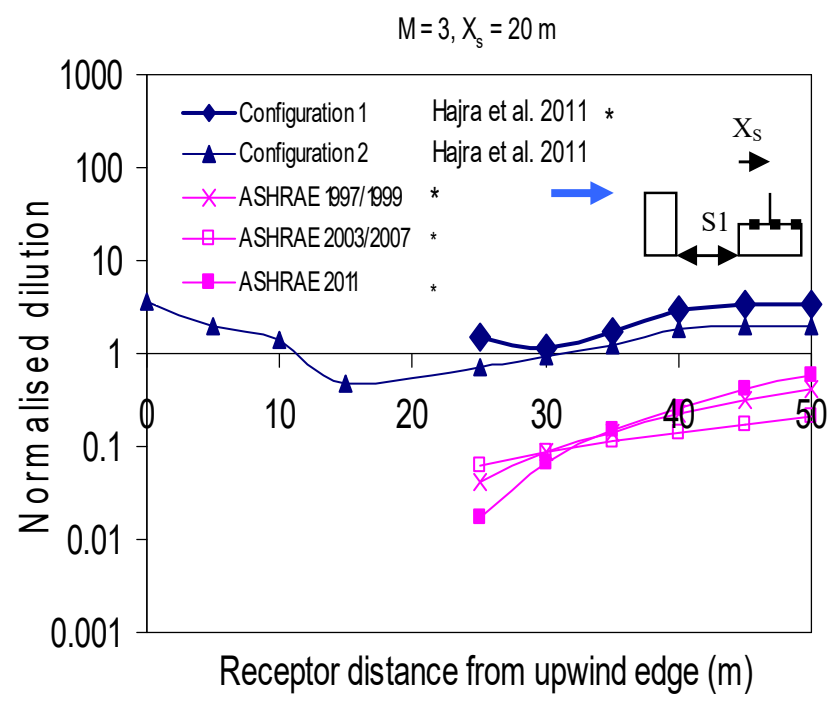

b)

Figure 3. Normalised dilution on rooftop of low building $\left(B_{1}\right)$ for $h_{s}=1 \mathrm{~m}, X_{s}=20 \mathrm{~m}$ and $\mathrm{S} 1=20 \mathrm{~m}$ : a) $\mathrm{M}=1$; d) $\mathrm{M}=3$ (* Dilution estimates were only found downwind of the stack)

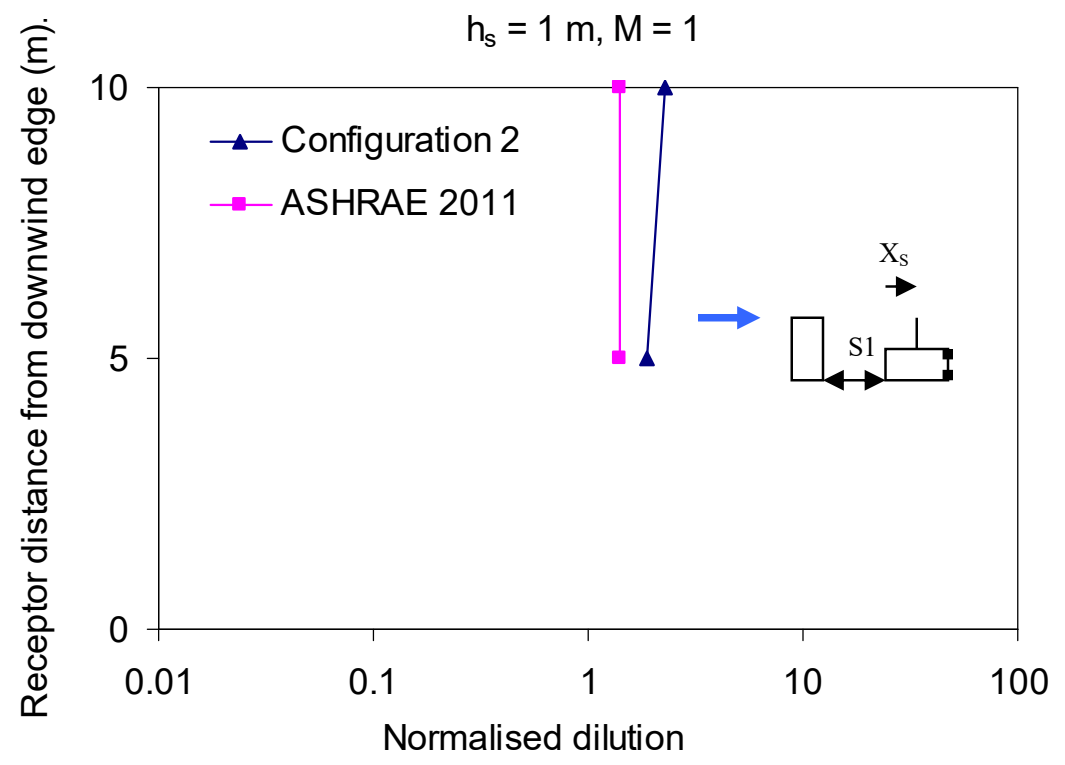

Figure 4. Normalised dilution on leeward wall of the low building $\left(B_{1}\right)$ for $X_{s}=20 \mathrm{~m}$ and $\mathrm{S} 1=20 \mathrm{~m}$ 


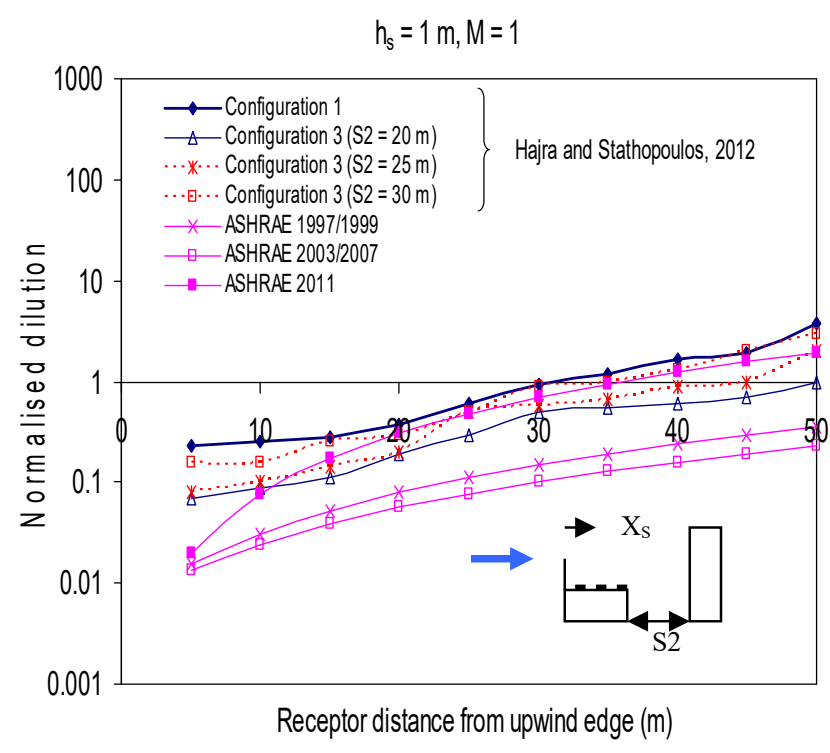

a)

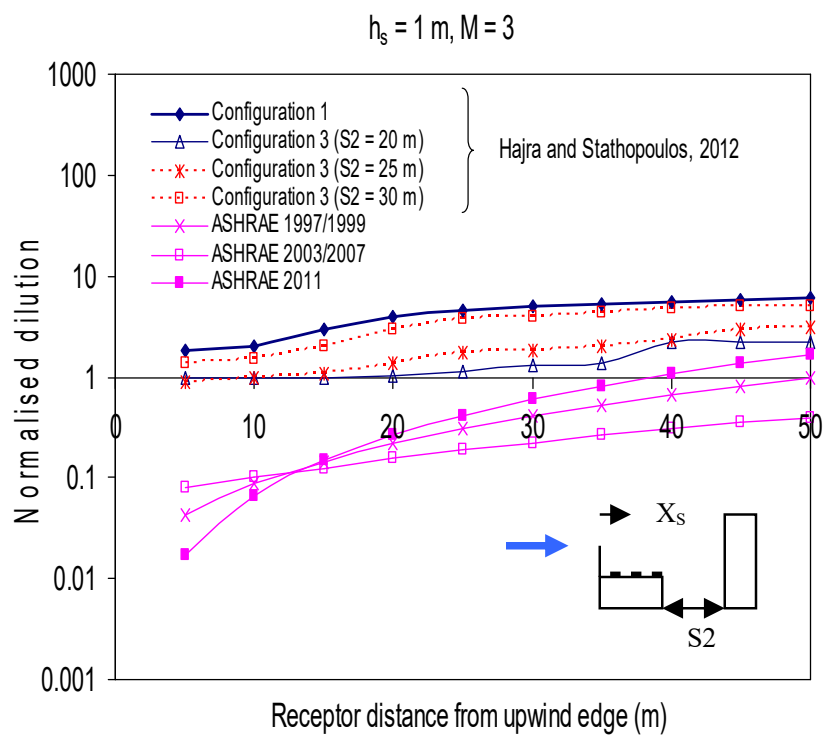

b)

Figure 5. Normalised dilution on rooftop of low building $\left(B_{1}\right)$ for different spacing (S2) and $X_{s}=0:$ a) $M=1$; b) $M=3$ 